University of Nebraska - Lincoln

DigitalCommons@University of Nebraska - Lincoln

\title{
Assessing net ecosystem carbon exchange of U.S. terrestrial ecosystems by integrating eddy covariance flux measurements and satellite observations
}

\author{
Jingfeng Xiao \\ Purdue University, j.xiao@unh.edu \\ Qianlai Zhuang \\ Purdue University \\ Beverly E. Law \\ Oregon State University, bev.law@oregonstate.edu \\ Dennis D. Baldocchi \\ University of California - Berkeley, baldocchi@berkeley.edu \\ Jiquan Chen \\ University of Toledo, jiquan.chen@utoledo.edu \\ Part of the Natural Resources and Conservation Commons \\ See next page for additional authors
}

Xiao, Jingfeng; Zhuang, Qianlai; Law, Beverly E.; Baldocchi, Dennis D.; Chen, Jiquan; Richardson, Andrew D.; Melillo, Jerry M.; Davis, Kenneth J.; Hollinger, David Y.; Wharton, Sonia; Oren, Ram; Noormets, Asko; Fischer, Marc L.; Verma, Shashi; Cook, David R.; Sun, Ge; McNulty, Steve; Wofsy, Steven C.; Bolstad, Paul V.; Burns, Sean P.; Curtis, Peter S.; Drake, Bert G.; Falk, Matthias; Foster, David R.; Gu, Lianhong; Hadley, Julian L.; Katul, Gabriel G.; Litvak, Marcy; Ma, Siyan; Martin, Timothy A.; Matamala, Roser; Meyers, Tilden P.; Monson, Russell K.; Munger, J. William; Oechel, Walter C.; Kyaw Tha Paw, U.; Schmid, Hans Peter; Scott, Russell L.; Starr, Gregory; Suyker, Andrew E.; and Torn, Margaret S., "Assessing net ecosystem carbon exchange of U.S. terrestrial ecosystems by integrating eddy covariance flux measurements and satellite observations" (2011). Papers in Natural Resources. 326.

https://digitalcommons.unl.edu/natrespapers/326

This Article is brought to you for free and open access by the Natural Resources, School of at DigitalCommons@University of Nebraska - Lincoln. It has been accepted for inclusion in Papers in Natural Resources by an authorized administrator of DigitalCommons@University of Nebraska - Lincoln. 


\section{Authors}

Jingfeng Xiao, Qianlai Zhuang, Beverly E. Law, Dennis D. Baldocchi, Jiquan Chen, Andrew D. Richardson, Jerry M. Melillo, Kenneth J. Davis, David Y. Hollinger, Sonia Wharton, Ram Oren, Asko Noormets, Marc L. Fischer, Shashi Verma, David R. Cook, Ge Sun, Steve McNulty, Steven C. Wofsy, Paul V. Bolstad, Sean P. Burns, Peter S. Curtis, Bert G. Drake, Matthias Falk, David R. Foster, Lianhong Gu, Julian L. Hadley, Gabriel G. Katul, Marcy Litvak, Siyan Ma, Timothy A. Martin, Roser Matamala, Tilden P. Meyers, Russell K. Monson, J. William Munger, Walter C. Oechel, U. Kyaw Tha Paw, Hans Peter Schmid, Russell L. Scott, Gregory Starr, Andrew E. Suyker, and Margaret S. Torn 


\section{Assessing net ecosystem carbon exchange of U.S. terrestrial ecosystems by integrating eddy covariance flux measurements and satellite observations}

Jingfeng Xiao ${ }^{a}, *$, Qianlai Zhuang ${ }^{b}$, Beverly E. Law ${ }^{c}$, Dennis D. Baldocchi ${ }^{d}$, Jiquan Chen ${ }^{e}$, Andrew D. Richardson ${ }^{f}$, Jerry M. Melillog ${ }^{g}$, Kenneth J. Davis ${ }^{h}$, David Y. Hollinger ${ }^{i}$, Sonia Wharton ${ }^{j}$, Ram Oren $^{\mathrm{k}}$, Asko Noormets ${ }^{\mathrm{l}}$, Marc L. Fischer ${ }^{\mathrm{m}}$, Shashi B. Verma ${ }^{\mathrm{n}}$, David R. Cook ${ }^{\mathrm{o}}$, Ge Sun $^{\mathrm{p}}$, Steve McNulty ${ }^{\mathrm{p}}$, Steven C. Wofsy ${ }^{\mathrm{q}}$, Paul V. Bolstad ${ }^{\mathrm{r}}$, Sean P. Burns ${ }^{\mathrm{s}}$, Peter S. Curtis ${ }^{\mathrm{t}}$, Bert G. Drake ${ }^{\mathrm{u}}$, Matthias Falk ${ }^{\mathrm{j}}$, David R. Foster ${ }^{\mathrm{v}}$, Lianhong Gu ${ }^{\mathrm{w}}$, Julian L. Hadley ${ }^{\mathrm{x}}$, Gabriel G. Katul ${ }^{\mathrm{k}}$, Marcy Litvak ${ }^{\mathrm{y}}$, Siyan Ma ${ }^{\mathrm{d}}$, Timothy A. Martin ${ }^{\mathrm{z}}$, Roser Matamala ${ }^{\mathrm{aa}}$, Tilden P. Meyers ${ }^{\text {bb }}$, Russell K. Monson ${ }^{\text {s }}$, J. William Munger ${ }^{c c}$, Walter C. Oechel ${ }^{\text {dd }}$, U. Kyaw Tha Paw ${ }^{\mathrm{j}}$, Hans Peter Schmid ${ }^{\text {ee,ff }}$, Russell L. Scott ${ }^{\text {gg }}$, Gregory Starr ${ }^{\text {hh }}$, Andrew E. Suyker ${ }^{\mathrm{n}}$, Margaret S. Torn ${ }^{\mathrm{ii}}$

a Department of Earth E'Atmospheric Sciences, Purdue Climate Change Research Center, Purdue University, West Lafayette, IN 47907, USA

${ }^{\mathrm{b}}$ Department of Earth E Atmospheric Sciences, Department of Agronomy, Purdue Climate Change Research Center, Purdue University, West Lafayette, IN 47907, USA

${ }^{c}$ College of Forestry, Oregon State University, Corvallis, OR 97331, USA

d Ecosystem Science Division, Department of Environmental Science, Policy and Management, University of California, Berkeley, CA 94720, USA

e Department of Environmental Sciences, University of Toledo, Toledo, OH 43606, USA

${ }^{\mathrm{f}}$ Department of Organismic and Evolutionary Biology, Harvard University, Cambridge, MA 02138, USA

${ }^{g}$ Ecosystems Center, Marine Biological Laboratory, Woods Hole, MA, USA

h Department of Meteorology, Pennsylvania State University, University Park, PA 16802, USA

i USDA Forest Service, Northeastern Research Station, Durham, NH 03824, USA

${ }^{\mathrm{j}}$ Department of Land, Air and Water Resources, University of California, Davis, CA 95616, USA

k Nicholas School of the Environment, Duke University, Durham, NC 27708, USA

${ }^{1}$ Department of Forestry and Environmental Resources and Southern Global Change Program, North Carolina State University, Raleigh, NC 27695, USA

${ }^{\mathrm{m}}$ Lawrence Berkeley National Laboratory, Environmental Energy Technologies Division, Atmospheric Science Department, Berkeley, CA 94720, USA

${ }^{\mathrm{n}}$ School of Natural Resources, University of Nebraska-Lincoln, Lincoln, NE 68583, USA

${ }^{\circ}$ Argonne National Laboratory, Environmental Science Division, Argonne, IL 60439, USA

p USDA Forest Service, Southern Research Station, Raleigh, NC 27606, USA

${ }^{\mathrm{q}}$ Division of Engineering and Applied Science/Department of Earth and Planetary Science, Harvard University, Cambridge, MA 02138, USA

${ }^{\mathrm{r}}$ Department of Forest Resources, University of Minnesota, St. Paul, MN 55108, USA

${ }^{s}$ Department of Ecology and Evolutionary Biology, University of Colorado, Boulder, CO 80309, USA

${ }^{\mathrm{t}}$ Department of Evolution, Ecology, and Organismal Biology, Ohio State University, Columbus, OH 43210, USA

u Smithsonian Environmental Research Center, Edgewater, MD 21037, USA

${ }^{v}$ Harvard Forest and Department of Organismic and Evolutionary Biology, Harvard University, Petersham, MA 01366, USA

${ }^{w}$ Oak Ridge National Laboratory Environmental Sciences Division, Oak Ridge, TN 37831, USA

x Harvard Forest, Harvard University, Petersham, MA 01366, USA

y Department of Biology, University of New Mexico, Albuquerque, NM 87131, USA

${ }^{\mathrm{z}}$ School of Forest Resources \& Conservation, University of Florida, Gainesville, FL 32611, USA

aa Argonne National Laboratory, Biosciences Division, Argonne, IL 60439, USA

bb NOAA/ARL, Atmospheric Turbulence and Diffusion Division, Oak Ridge, TN 37831, USA

${ }^{c c}$ Department of Earth and Planetary Sciences, Harvard University, Cambridge, MA 02138, USA

dd Department of Biology, San Diego State University, San Diego, CA 92182, USA

ee Department of Geography, Indiana University, Bloomington, IN 47405, USA

${ }^{\mathrm{ff}}$ Atmospheric Environmental Research, Institute of Meteorology and Climate Research, Research Center Karlsruhe (FZK/IMK-IFU), Kreuzeckbahnstr,

19, 82467 Garmisch-Partenkirchen, Germany

gg USDA-ARS Southwest Watershed Research Center, Tucson, AZ 85719, USA

hh Department of Biological Sciences, University of Alabama, Tuscaloosa, AL 35487, USA

ii Lawrence Berkeley National Laboratory, Earth Science Division, Berkeley, CA 94720, USA

\footnotetext{
* Corresponding author at: Complex Systems Research Center, University of New Hampshire, Durham, NH 03824 , USA. Tel.: +1 603862 1873.

E-mail address: j.xiao@unh.edu (J.Xiao).
} 


\section{A R T I C L E I N F O}

\section{Article history:}

Received 19 July 2009

Received in revised form 20 August 2010

Accepted 6 September 2010

\section{Keywords:}

Net ecosystem carbon exchange

Eddy covariance

MODIS

Carbon sink

U.S.

Interannual variability

Drought

Disturbance

\begin{abstract}
A B S T R A C T
More accurate projections of future carbon dioxide concentrations in the atmosphere and associated climate change depend on improved scientific understanding of the terrestrial carbon cycle. Despite the consensus that U.S. terrestrial ecosystems provide a carbon sink, the size, distribution, and interannual variability of this sink remain uncertain. Here we report a terrestrial carbon sink in the conterminous U.S. at $0.63 \mathrm{pg} \mathrm{C} \mathrm{yr}^{-1}$ with the majority of the sink in regions dominated by evergreen and deciduous forests and savannas. This estimate is based on our continuous estimates of net ecosystem carbon exchange (NEE) with high spatial $(1 \mathrm{~km}$ ) and temporal (8-day) resolutions derived from NEE measurements from eddy covariance flux towers and wall-to-wall satellite observations from Moderate Resolution Imaging Spectroradiometer (MODIS). We find that the U.S. terrestrial ecosystems could offset a maximum of $40 \%$ of the fossil-fuel carbon emissions. Our results show that the U.S. terrestrial carbon sink varied between 0.51 and $0.70 \mathrm{pg} \mathrm{C} \mathrm{yr}^{-1}$ over the period 2001-2006. The dominant sources of interannual variation of the carbon sink included extreme climate events and disturbances. Droughts in 2002 and 2006 reduced the U.S. carbon sink by $\sim 20 \%$ relative to a normal year. Disturbances including wildfires and hurricanes reduced carbon uptake or resulted in carbon release at regional scales. Our results provide an alternative, independent, and novel constraint to the U.S. terrestrial carbon sink.
\end{abstract}

(C) 2010 Elsevier B.V. All rights reserved.

\section{Introduction}

More accurate quantification of net carbon dioxide $\left(\mathrm{CO}_{2}\right)$ exchange over regions, continents, or the globe can improve our understanding of the feedbacks between the terrestrial biosphere and the atmosphere in the context of global change and facilitate climate policy-making (IPCC, 2007; Peters et al., 2007). Despite the consensus that U.S. terrestrial ecosystems provide a carbon sink, the size and distribution of the sink still remain uncertain (Houghton et al., 1999; Caspersen et al., 2000; Schimel et al., 2000; Pacala et al., 2001; SOCCR, 2007). More importantly, the interannual variability of this carbon sink is not well understood. Extreme climate events (Ciais et al., 2005; Zeng et al., 2005; Xiao et al., 2009, 2010) and disturbances (Law et al., 2004; Chambers et al., 2007; Amiro et al., in press; Xiao et al., 2010) could substantially affect ecosystem carbon fluxes and lead to significant year-to-year variations in regional terrestrial carbon budgets. Here we integrate eddy covariance flux measurements and wall-to-wall satellite observations to assess recent U.S. net ecosystem carbon exchange (NEE) and yearto-year variations.

Inventory studies of biomass (Clark et al., 2001; Goodale et al., 2002) and soil carbon (Lal et al., 2001) are traditionally used to quantify NEE of an ecosystem over multiple years (Baldocchi, 2003). The eddy covariance technique has emerged as an alternative way to assess NEE (Baldocchi et al., 2001). Eddy covariance flux towers have been providing continuous measurements of ecosystem-level exchange of $\mathrm{CO}_{2}$ spanning diurnal, synoptic, seasonal, and interannual time scales since the early 1990s (Wofsy et al., 1993; Baldocchi et al., 2001). The AmeriFlux network consists of eddy covariance flux towers encompassing a large range of climate and biome types, and provides the longest, most extensive, and most reliable measurements of plot-scale NEE with high temporal resolution for the U.S. These NEE estimates represent fluxes at the scale of the tower footprint with longitudinal dimensions ranging between a hundred meters and several kilometers depending on homogeneous vegetation and fetch (Schmid, 1994; Göckede et al., 2008). To examine terrestrial carbon cycling over regions or continents, therefore, eddy flux measurements need to be upscaled to these large areas (Xiao et al., 2008, 2010).

Satellite remote sensing provides observations of ecosystems with spatially and temporally consistent coverage, and is a valuable tool for upscaling carbon fluxes to regional or continental scales (Xiao et al., 2008, 2010). The Moderate Resolution Imaging Spectroradiometer (MODIS) on board the NASA' Terra and Aqua satellites provides particularly useful observations as the MODIS sensors view the entire Earth's surface every one to two days and acquire data with 36 spectral bands and $250 \mathrm{~m}-1 \mathrm{~km}$ spatial resolution. Several recent studies have upscaled eddy flux measurements to large areas using satellite data (e.g., Papale and Valentini, 2003; Yamaji et al., 2007; Wylie et al., 2007; Xiao et al., 2008, 2010). Moreover, some of the resulting flux estimates have been used to assess regional terrestrial carbon uptake. For example, Papale and Valentini (2003) estimated annual NEE for European forests using the NEE estimates. Yamaji et al. (2007) used the NEE estimates to assess the annual NEE of deciduous forests in Japan. Wylie et al. (2007) examined the magnitude and interannual variability of annual NEE for grasslands in the northern Great Plains. Xiao et al. (2010) examined the magnitude, patterns, and interannual variability of gross primary productivity (GPP) for the conterminous U.S.

Here we use our predictive NEE model developed from eddy flux and MODIS data (Xiao et al., 2008) to produce continuous NEE estimates with high spatial $(1 \mathrm{~km})$ and temporal (8-day) resolutions for the conterminous U.S. over the period 2000-2006. Our continuous NEE estimates along with our previous GPP estimates (Xiao et al., 2010) for the U.S. were both derived from eddy covariance (EC) flux measurements and MODIS data, and are referred to as EC-MOD. We then use our continuous NEE estimates to assess the magnitude, distribution, and interannual variability of recent U.S. ecosystem carbon exchange. One of the main innovations in our estimates is the use of daily NEE measurements derived from continuous observations from eddy covariance flux towers. These measurements represent direct samples of net $\mathrm{CO}_{2}$ exchange from sites encompassing a wide variety of U.S. biomes and climate types. These data were not utilized in previous U.S. carbon budget studies (e.g., Houghton et al., 1999; Caspersen et al., 2000; Schimel et al., 2000; Pacala et al., 2001; SOCCR, 2007). Our analysis provides an alternative, independent, and novel perspective on recent U.S. ecosystem carbon exchange.

\section{Data and methods}

\subsection{Ameriflux data}

NEE is the difference of two large carbon fluxes - photosynthesis (GPP) and ecosystem respiration $\left(R_{\mathrm{e}}\right)$. To avoid compensating errors the basic processes underlying ecosystem carbon uptake and release should both be modeled well (Richardson et al., 2007). Unlike most modeling methods, our approach directly estimates NEE, which could avoid the compensating errors. We integrated 


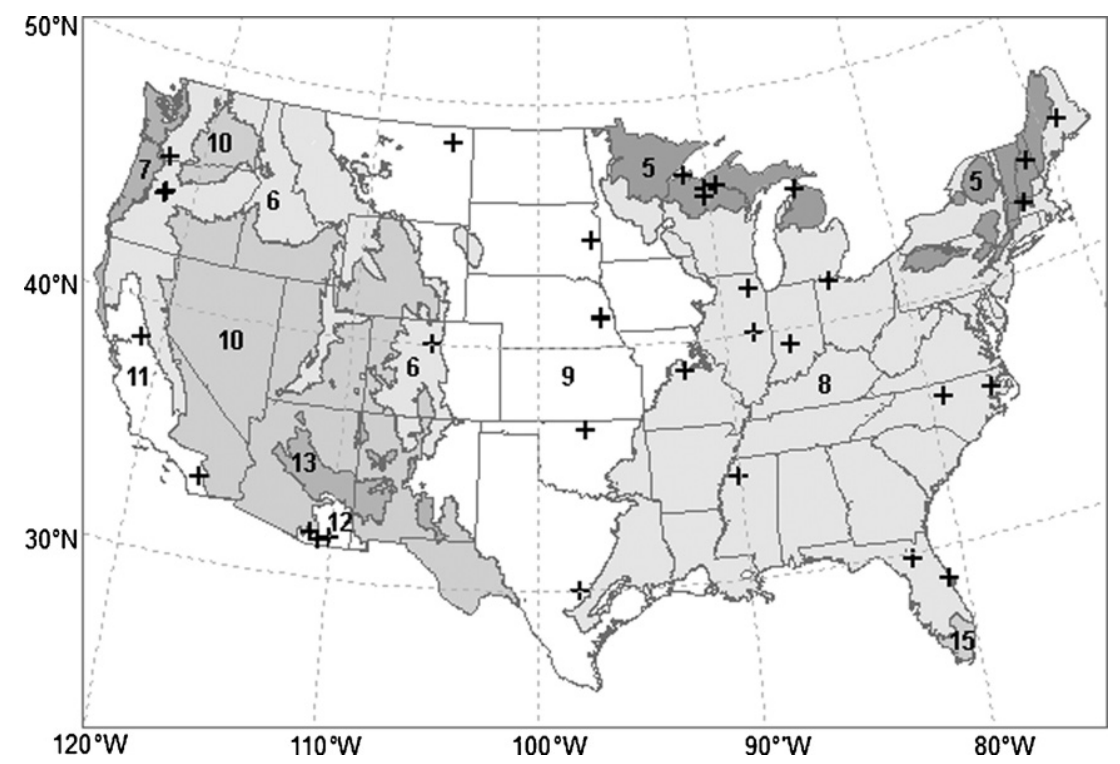

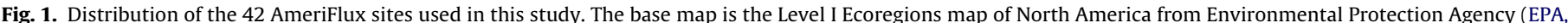

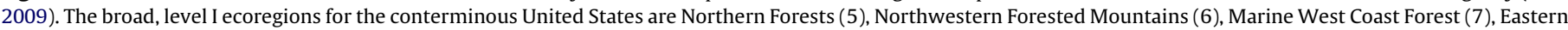

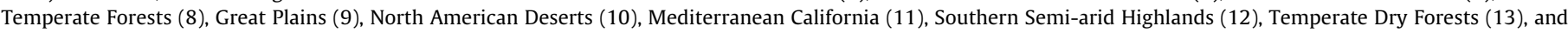
Tropical Wet Forests (15).

eddy flux measurements and MODIS data to estimate NEE of U.S. ecosystems. We obtained the Level 4 NEE data for 42 Ameriflux sites over the period 2000-2006. These sites are distributed across the conterminous U.S. (Fig. 1). The AmeriFlux NEE data we used were described in detail by Xiao et al. (2008).

The Level 4 product consists of NEE data with four different time steps, including half-hourly, daily, 8-day, and monthly. NEE was calculated using the storage obtained from the discrete approach or using a vertical $\mathrm{CO}_{2}$ profile system, and was gap-filled using the artificial neural network method. We used 8-day NEE data $\left(\mathrm{gC} \mathrm{m}^{-2} \mathrm{day}^{-1}\right)$ to match the compositing intervals of MODIS data.

\subsection{Predictive model}

The development of our predictive model has been fully described by Xiao et al. (2008). Here we briefly summarize our approach. We combined site-specific eddy flux measurements and MODIS data to develop a predictive NEE model using piecewise regression models. The independent variables of the model included a variety of MODIS data products: surface reflectance (Vermote and Vermeulen, 1999), daytime and nighttime land surface temperature (LST) (Wan et al., 2002), and enhanced vegetation index (EVI) (Huete et al., 2002) as well as the normalized difference water index (NDWI; Gao, 1996) derived from surface reflectance. These data can partly account for a variety of physical, physiological, atmospheric, hydrologic, and edaphic variables that affect NEE (Xiao et al., 2008). For each site, we obtained MODIS ASCII subsets consisting of $7 \mathrm{~km} \times 7 \mathrm{~km}$ regions centered on the flux tower, including surface reflectance, daytime and nighttime LST, and EVI over the period 2000-2006 from the Oak Ridge National Laboratory's Distributed Active Archive Center. For each variable, we extracted the average values for the central $3 \mathrm{~km} \times 3 \mathrm{~km}$ area within the $7 \mathrm{~km} \times 7 \mathrm{~km}$ cutouts rather than the values of the $1 \mathrm{~km} \times 1 \mathrm{~km}$ pixel corresponding to the tower to account for the inherent geolocation error of MODIS data and better represent the flux tower footprint.

We then developed the predictive NEE model using piecewise regression models. We divided the site-level data set of AmeriFlux and MODIS data into a training set (2000-2004) and a test set (2005-2006). The training and test sets were used to develop and evaluate the predictive model, respectively. The performance of the model was evaluated using three statistical measures: average error, relative error, and correlation coefficient. The model achieved reasonable accuracy to estimate NEE at the site level (Xiao et al., 2008).

In addition to the validation in the temporal domain using the test data (Xiao et al., 2008), we also used cross-validation to obtain an alternative measure of the predictive accuracy of our model. We used $k$-fold cross-validation, in which the cases are divided into $k$ blocks of roughly the same size and target value distribution. For each block, a predictive model is constructed from the cases in the remaining blocks, while the cases in the hold-out block is then used to test the performance of the model (RuleQuest, 2008). The 10-fold cross-validation also showed that our model predicted NEE fairly well (Fig. $2 ; R^{2}=0.67, p<0.0001$; $\mathrm{RMSE}=1.45 \mathrm{gC} \mathrm{m}^{-2} \mathrm{day}^{-1}$ ).

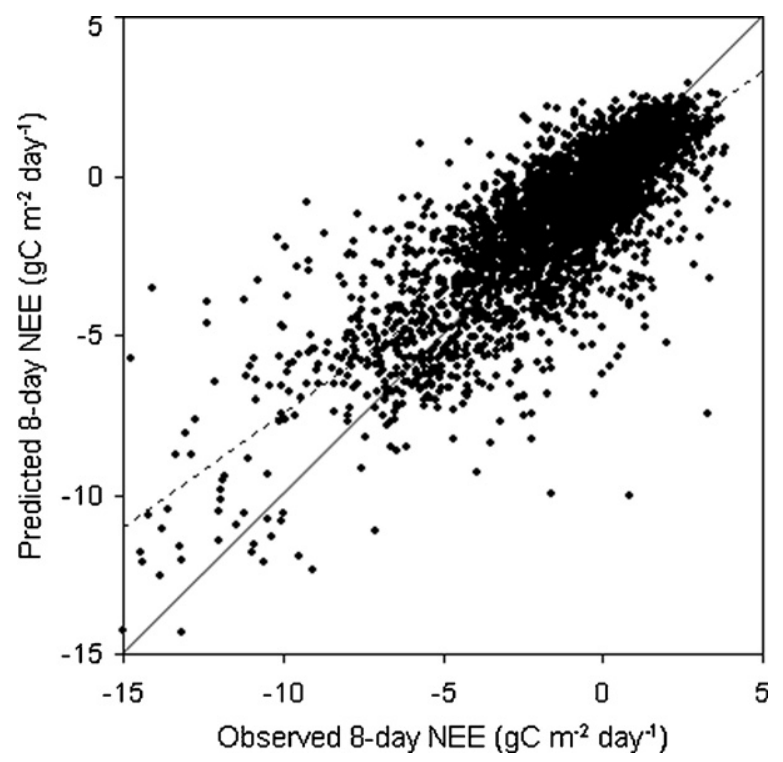

Fig. 2. Observed 8-day NEE versus predicted 8-day NEE for 10-fold cross-validation. 


\subsection{Network representativeness}

The Ameriflux sites we used involve a wide variety of ecosystem types (Fig. 1) and are fairly representative of typical U.S. climate types (Xiao et al., 2008). Moreover, some forest sites are at different stages since stand replacing disturbance, which are located in disturbance clusters of sites, such as Metolius intermediate aged ponderosa pine (Oregon), Metolius new young pine (Oregon), Intermediate hardwood (Wisconsin), and Mature red pine (Wisconsin). In addition, some sites have received treatment, including the Howland Forest West Tower (Maine: nitrogen fertilizer) and the Mead cropland sites (Nebraska; irrigation versus rainfed; continuous maize versus maize/soybean rotation). Hargrove et al. (2003) carried out an analysis of multivariate environmental "data space" (including such factors as elevation, means and extremes of temperature, monthly precipitation, soil characteristics and other factors) and concluded that the central, Midwestern, and northeastern part of the U.S. were well represented by the AmeriFlux network at that time, with the southern, southwestern, and Pacific Northwest environments less well represented by existing tower sites. Since that analysis new sites have been established in Florida, Texas, New Mexico, Arizona, and Southern California, which substantially increased the coverage and representativeness of the south and southwestern parts of the U.S.

We assessed the representativeness of the AmeriFlux network using the Euclidean distance between each grid cell and the eddy flux sites in the attribute space, following Yang et al. (2008). The attribute space we used consists of all the numerical variables included in the predictive model: bands 1-6, NDWI, daytime LST, nighttime LST, and EVI. The Euclidean distance measures the similarity between each grid cell and eddy flux sites (Yang et al., 2008). The Euclidian distance (ED) between two points $X=\left(x_{1}, x_{2}, \ldots, x_{n}\right)$ and $Y=\left(y_{1}, y_{2}, \ldots, y_{n}\right)$ is defined as:

$\mathrm{ED}=\sqrt{\sum_{n}\left(x_{i}-y_{i}\right)^{2}}$

where $X$ is the attribute vector of a grid cell, while $Y$ is the mean attribute vector of eddy flux sites within a given vegetation type. Daytime and nighttime LST were scaled to the range of -1 and +1 using their minimum and maximum values over the period 2000-2006 to minimize the influence of the magnitude of these variables on the calculation of ED. We calculated ED for each grid cell for each 8-day interval. For each year, the mean ED was calculated from all 8-day ED values for each grid cell. We then calculated the minimum ED for each grid cell over the period 2000-2006.

The resulting similarity map (Fig. 3) showed that the Great Lakes region, the Great Plains, a part of the Pacific West, and northeastern forests exhibited highest similarity to the AmeriFlux network; the Southeast and the Gulf Coast region exhibited intermediate similarity, while a large part of the Rocky Mountain region, northeastern North Dakota and western Minnesota had lowest similarity. This indicates that the Great Lakes region, the Great Plains, a part of Pacific West, and northeastern forests are fairly represented by Ameriflux sites, while a large part of the Rocky Mountain region, northeastern North Dakota and western Minnesota were underrepresented.

\subsection{MODIS data}

To estimate NEE at the continental scale, we obtained wallto-wall MODIS data including surface reflectance, daytime and nighttime LST, and EVI from the Earth Observing System (EOS) Data Gateway for each 8-day interval from February 2000 to December 2006. For each variable, the quality of the value of each pixel

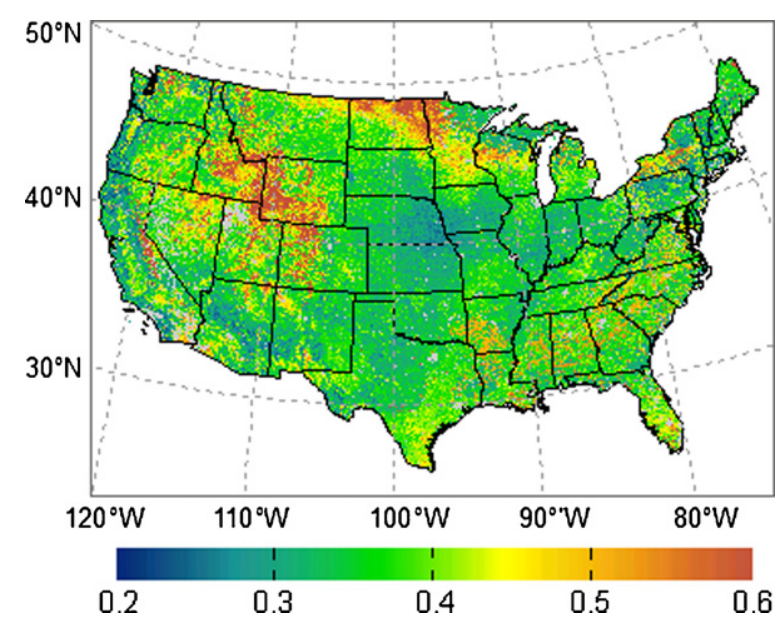

Fig. 3. Representativeness of the AmeriFlux network measured by the similarity between each grid cell and eddy flux sites using the Euclidean distance in the attribute space. The similarity is proportional to the magnitude of the distance.

( $1 \mathrm{~km}$ ) was determined using the quality assurance (QA) flags, and the bad-quality value was replaced using a linear interpolation approach (Xiao et al., 2008). The NDWI was also calculated from band 2 (near-infrared) and band 6 (shortwave infrared) of the surface reflectance product. Each 16-day EVI composite was used for two 8-day intervals corresponding to the composting interval of other MODIS products. We also obtained the land cover type for each cell from the $1 \mathrm{~km}$ MODIS land cover map (Friedl et al., 2002), and reclassified the vegetation classes to seven broader classes: evergreen forests, deciduous forests, mixed forests, shrublands, savannas, grasslands, and croplands (Xiao et al., 2008).

\subsection{Model prediction}

We then used our predictive model (Xiao et al., 2008) to estimate NEE for each $1 \mathrm{~km} \times 1 \mathrm{~km}$ cell across the conterminous U.S. for each 8-day interval from February 2000 to December 2006 using the wall-to-wall MODIS data. The land-cover type for each pixel was obtained from the reclassified MODIS land-cover map. For each grid cell, we calculated annual NEE $\left(\mathrm{gC} \mathrm{m}^{-2} \mathrm{yr}^{-1}\right)$ for each year from our 8-day NEE estimates.

We produced the probability distribution of our mean annual NEE values over the period 2001-2006 across the conterminous U.S., and then compared this histogram with that of the compiled database of published eddy flux measurements over the globe (Baldocchi, 2008) (Fig. 4). This database contains 504 site-years of data from 125 study sites over the globe. Both probability distributions were negatively skewed, indicating that overall, the terrestrial ecosystems absorbed carbon from the atmosphere. Moreover, these two probabilistic histograms had similar ranges and almost identical means and standard deviations. The similarity of these two distributions indicated that our annual estimates generally captured the expected mean, range, and spatial variability of published annual NEE.

We then examined the magnitude, distribution, and year-toyear variations of annual NEE. The coefficient of variation (CV) and annual anomalies were used to assess the interannual variability of NEE. CV is defined as the ratio of standard deviation to the mean. For each grid cell, the annual NEE values over the period 2001-2006 were used to calculate the mean and standard deviation of annual $\mathrm{NEE}$, and $\mathrm{CV}$ was then calculated as the standard deviation divided by the mean. The CV value of each grid cell indicates the variability of annual NEE over the 6-year period. For grid cells with mean annual NEE within -1 to $+1 \mathrm{~g} \mathrm{C} \mathrm{m}^{-2} \mathrm{yr}^{-1}, \mathrm{CV}$ was assigned as 0 to avoid unreasonably large CV values in absolute magnitude. For each 


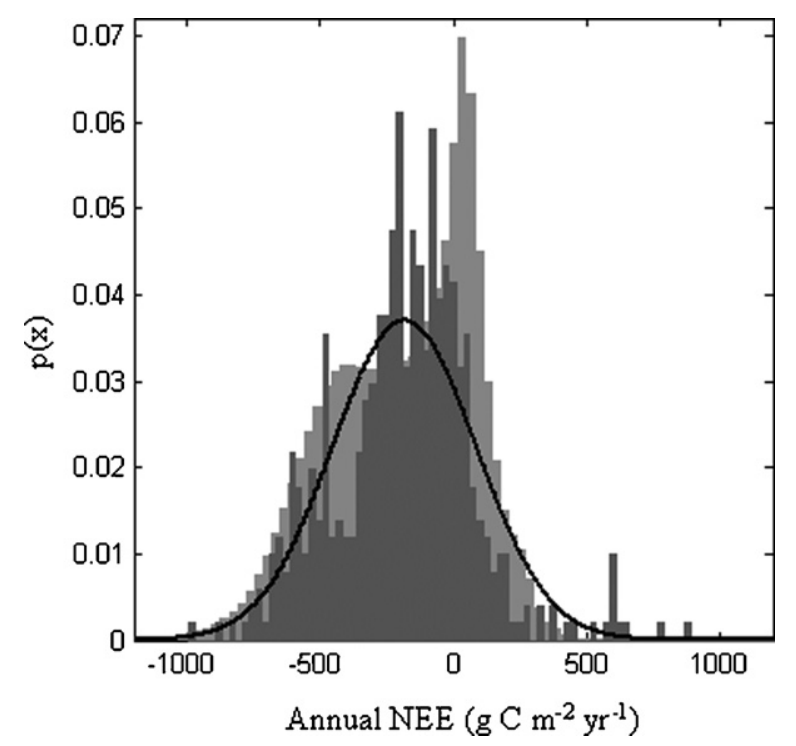

Fig. 4. Probabilistic histograms of estimated and published annual NEE. Dark gray bars indicate estimated annual NEE values, and light gray bars indicate published annual NEE from 506 site-years of data over the globe. Superimposed (black curve) is a Gaussian probability distribution. The means of estimated and published annual NEE are -189.5 and $-182.4 \mathrm{gC} \mathrm{m}^{-2} \mathrm{yr}^{-1}$, respectively; their standard deviations are 272.3 and 269.6 , respectively.

year, we also calculated the anomaly of annual NEE relative to the mean over the 6-year period.

\subsection{Climate and disturbance data}

We used precipitation, fire severity, and wind fields data to assess the impacts of drought, fire, and hurricane on NEE. We obtained monthly precipitation data over the period 1970-2006 from the PRISM (Parameter-elevation Regressions on Independent Slopes Model) group (PRISM, 2004). PRISM produces a high-quality gridded climate data set using station observations of precipitation, temperature, and other climatic factors. The spatial resolution of this data set is $4 \mathrm{~km} \times 4 \mathrm{~km}$. We calculated the average annual precipitation over the period 1970-1999, and then calculated the anomaly of annual precipitation for each year over the period 2001-2006 relative to the long-term mean (1970-1999).

We also used fire severity data for the Biscuit fire in Oregon. The Biscuit Fire was among the largest forest fires in modern United States history, encompassing $>2000 \mathrm{~km}^{2}$ primarily within the Rogue-Siskiyou National Forest (RSNF) in southwest Oregon (Thompson et al., 2007). Fire severity was based on the difference normalized burn ratio (dNBR) (Lutes et al., 2004) from Landsat Thematic Mapper (TM) data acquired before and immediately after the fire. dNBR is a quantitative indicator of aboveground green biomass and changes in soil moisture and color as well as consumption of down fuels (Lutes et al., 2004). dNBR has proven an effective measure of burn severity of forest ecosystems (Brewer et al., 2005; Miller and Yool, 2002). Different degrees of fire severity were identified: little or no change, green and dead mixed, dead trees with needles, and dead trees without needles (Thompson et al., 2007).

Finally, we obtained tropical cyclone surface wind field data for hurricane Katrina (Powell et al., 1998) from the Atlantic Oceanographic and Meteorological Laboratory (AOML), National Oceanic and Atmospheric Administration (NOAA) (AOML, 2007). The wind field data was produced using the Hurricane Research Division (HRD) surface wind analysis system (Powell et al., 1998). The HRD approach to hurricane wind analysis requires the input of all available surface weather observations (e.g., ships, buoys, coastal platforms, surface aviation reports, etc.). We converted the wind

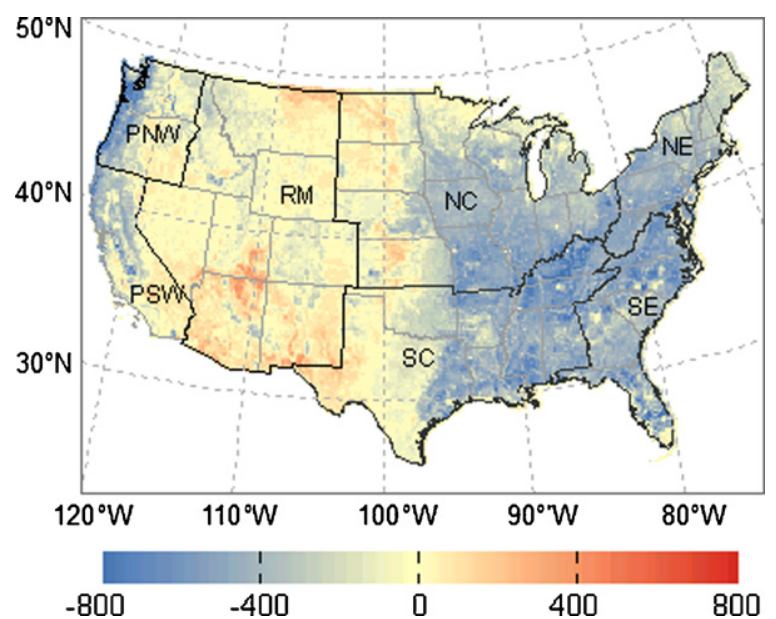

Fig. 5. Mean annual NEE for the conterminous U.S. over the period 2001-2006. Units are $\mathrm{gC} \mathrm{m}^{-2} \mathrm{yr}^{-1}$. Positive values indicate carbon release, and negative values indicate carbon uptake. Gray lines indicate state boundaries. Black lines indicate boundaries of geographical regions: Northeast (NE), Southeast (SE), North Central (NC), South Central (SC), Pacific Northwest (PNW), and Pacific Southwest (PSW).

fields for hurricane Katrina to isotaches, and extracted the isotachs representing tropical storm (39-73 $\mathrm{mph}$ ), category 1 (74-95 $\mathrm{mph}$ ), and category 2 (96-110 $\mathrm{mph}$ ) wind fields.

\section{Results and discussion}

\subsection{Annual NEE}

The 6-yr mean annual pattern of NEE is shown in Fig. 5. This represents the terrestrial part of the carbon cycle without fire emissions and immediate carbon loss due to the removal and burning of biomass. The temperate forests in the eastern U.S. absorbed carbon mainly because of forest regrowth following the abandonment of agricultural lands (Caspersen et al., 2000). Some regions in the west including the Rocky Mountains and the Pacific Coast also assimilated carbon. The dominant evergreen forests in the Pacific Coast region are highly productive as these ecosystems assimilated carbon even in the winter due to mild temperature and moist conditions (Waring and Franklin, 1979; Anthoni et al., 2002). For example, Douglas-fir, a major species in the Pacific Northwest and California, is known to be highly plastic and able to photosynthesize in winter when temperatures are above freezing. By contrast, many areas in the western U.S. including the Great Basin, the Colorado Plateau, and the western Great Plains were nearly carbon neutral due to sparse vegetation and large precipitation deficits. Drought could reduce GPP and net primary productivity (NPP), and lead to changes in heterotrophic respiration $\left(R_{\mathrm{h}}\right)$ occurring in the same direction but with a smaller magnitude (Xiao et al., 2009). These concurrent changes in NPP and $R_{\mathrm{h}}$ likely led to reduced annual NEE in absolute magnitude. A part of the Southwest provided minor carbon sources, while the small region in northeastern Arizona and southeastern Utah exhibited annual NEE greater than $200 \mathrm{gC} \mathrm{m}^{-2} \mathrm{yr}^{-1}$. This region was affected by moderate to severe drought in 2000-2003 and 2005, which likely resulted in a net carbon release over the 6 -year period. In addition, our predictive model utilized LST to account for $R_{\mathrm{e}}$, and the explanatory variables could not account for the sizes of soil carbon pools and litter. The relatively high temperatures in this region in the summer and the inability of our predictive model to account for soil carbon pools and litter may lead to overestimation of $R_{\mathrm{e}}$, which in turn can lead to reduced net carbon uptake $\left(R_{\mathrm{e}}<\mathrm{GPP}\right)$ or net carbon release $\left(R_{\mathrm{e}}>\mathrm{GPP}\right)$. 


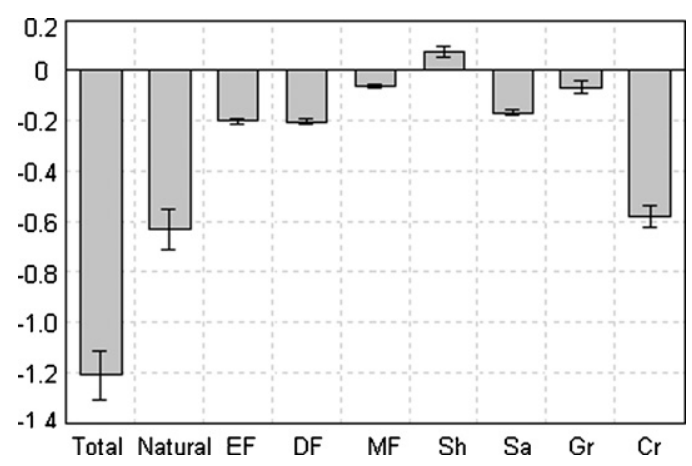

Fig. 6. Mean annual NEE for each vegetation type within the conterminous U.S. over the period 2001-2006: evergreen forests (EF), deciduous forests (DF), mixed forests (MF), shrublands (Sh), savannas (Sa), and grasslands (Gr). Units are $\mathrm{pg} \mathrm{C} \mathrm{yr}^{-1}$. The bars are the estimated mean annual NEE. The error bars indicate the standard deviation from the mean.

We examined the total annual NEE for U.S. and for each broad vegetation type over the period 2001-2006 (Fig. 6). On average, the total annual NEE for U.S. is $-1.21 \mathrm{pgC} \mathrm{yr}^{-1}$, with -0.63 for

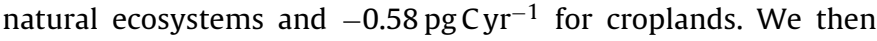
examined the magnitude of the U.S. terrestrial carbon sink using our annual NEE estimates. Croplands were not included here because the carbon absorbed by crops will be released back into the atmosphere due to the consumption of yields and the burning of biomass. We estimated total carbon sink in the conterminous U.S. at $0.63 \mathrm{pg} \mathrm{Cyr}^{-1}$ with the majority of the sink in regions dominated by evergreen and deciduous forests and savannas in nearly equal proportions of the total sink (Fig. 6). Our estimate did not include the immediate emissions from the burning of biomass in wildfires. We assumed that wildfire released $0.06 \mathrm{pg} \mathrm{C} \mathrm{yr}^{-1}$ as estimated by Wiedinmyer and Neff (2007), and then deducted fire emissions from our sink estimate. With fire emissions taken into consideration, our estimate of the U.S. carbon sink $\left(0.57 \mathrm{pg} \mathrm{C} \mathrm{yr}^{-1}\right)$ was at the higher end of the range $\left(0.30-0.58 \mathrm{~g} \mathrm{Cyr}^{-1}\right)$ estimated by Pacala et al. (2001) and between a recent estimate $\left(\sim 0.63 \mathrm{pg} \mathrm{C} \mathrm{yr}^{-1}\right)$ based on an inverse modeling approach (Deng et al., 2007) and the esti-

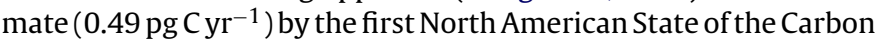
Cycle Report (SOCCR, 2007). Compared to previous approaches based on forest inventory measurements, ecosystem models, bookkeeping models, or atmospheric inverse modeling (e.g., Houghton et al., 1999; Caspersen et al., 2000; Schimel et al., 2000; Pacala et al., 2001; Deng et al., 2007; SOCCR, 2007), our approach integrated eddy flux measurements and wall-to-wall satellite observations, and provided an independent, alternative, and novel constraint to the recent U.S. terrestrial carbon sink. A quantitative breakdown of the 6-yr mean annual NEE map by geographical regions (Fig. 7) showed that the greatest carbon uptake occurred in the South Central region, followed by Southeast and Northeast. North Central and the Pacific Northwest had intermediate carbon sinks, while the Pacific Southwest had the lowest carbon uptake. The Rocky Mountain region was a minor carbon source.

A better understanding of the magnitude and spatial distribution of the U.S. carbon sink is helpful for successful carbon management strategies to mitigate fossil-fuel emissions or stabilize concentrations of greenhouse gases in the atmosphere (SOCCR, 2007). Our results show that the U.S. terrestrial ecosystems could offset $40 \%$ of the U.S. fossil fuel emissions (Fig. 7), suggesting that the U.S. ecosystems play an important role in slowing down the buildup of $\mathrm{CO}_{2}$ in the atmosphere. This is higher than the SOCCR estimate of $30 \%$, which was based on inventory data (SOCCR, 2007). The North Central $\left(0.42 \mathrm{pg} \mathrm{C} \mathrm{yr}^{-1}\right)$ and South Central $\left(0.40 \mathrm{pg} \mathrm{C} \mathrm{yr}^{-1}\right)$ regions had the largest carbon emissions due to consumption of fossil fuels (EIA, 2008), whereas $\sim 19 \%$ and $55 \%$ were offset by

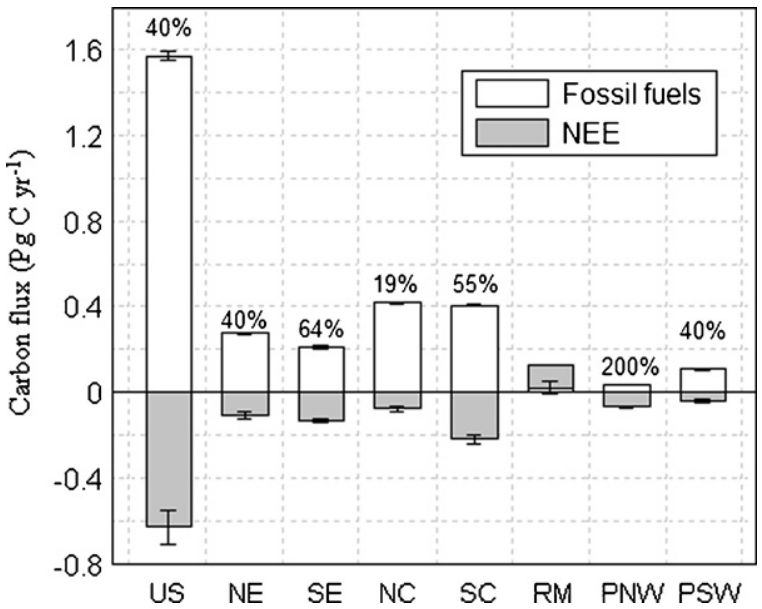

Fig. 7. Mean annual NEE per region for the period 2001-2006. White bars are the fossil fuel fluxes (Energy Information Administration, Department of Energy,

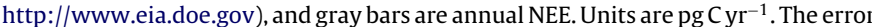
bars denote the standard deviation from the mean. The labels refer to the regions: Northeast (NE), Southeast (SE), North-Central (NC), South-Central(SC), Rocky Mountain (RM), Pacific Northwest (PNW), and Pacific Southwest (PSW). Numbers are the percentages that the fossil fuel fluxes were offset by ecosystem carbon uptake. No percentage was provided for the Rocky Mountain region because this region was a minor carbon source.

regional ecosystem carbon uptake, respectively. The Northeast and Southeast regions had intermediate fossil-fuel carbon emissions, and ecosystem carbon uptake in these regions offset $40 \%$ and $64 \%$ of the emissions, respectively. The Pacific Southwest also offset $40 \%$ of the regional carbon emissions. The Rocky Mountain region, however, provided a minor carbon source that was $\sim 0.1 \mathrm{pg} \mathrm{Cyr}^{-1}$ greater than fossil fuel emissions in the region. The Pacific Northwest region absorbed about twice as much carbon as emitted by the consumption of fossil fuels in the region, which likely puts the region at an advantage in carbon policy-making and trading. The quantification of the proportions of carbon emissions offset by ecosystem carbon uptake and their magnitudes have implications for carbon-management and climate policy-decision making, including the commitments of different states to the reduction of carbon emissions. It should be noted that our estimates represents the upper bounds of the capacity of U.S. ecosystems for sequestering carbon from the atmosphere because our NEE did not include fire emissions, immediate loss of carbon due to other disturbances and management, and other greenhouse gas emissions from croplands and pastures.

\subsection{Year-to-year variations}

Fig. 8 shows the interannual variability of NEE characterized by CV. Negative values indicate the interannual variability of carbon uptake, and positive values indicate the interannual variability of carbon release. CV generally exhibited larger spatial variability in regions with carbon release than in regions with carbon uptake. This is likely because ecosystems providing carbon sources are mainly distributed in arid and semi-arid regions, while ecosystems with carbon uptake are primarily distributed in humid and semihumid regions. The magnitude of annual NEE in arid and semi-arid region is often smaller than that in humid and semi-humid regions. Moreover, arid and semi-arid regions are characterized by larger temporal variability in water availability than humid and semihumid regions due to the variation in climate and weather at multiple scales and vegetation-soil water feedbacks (Snyder and Tartowski, 2006). Among regions with carbon release, the southern part of the western Great Plains, including western Texas, eastern New Mexico, and southeastern Colorado exhibited largest CV val- 


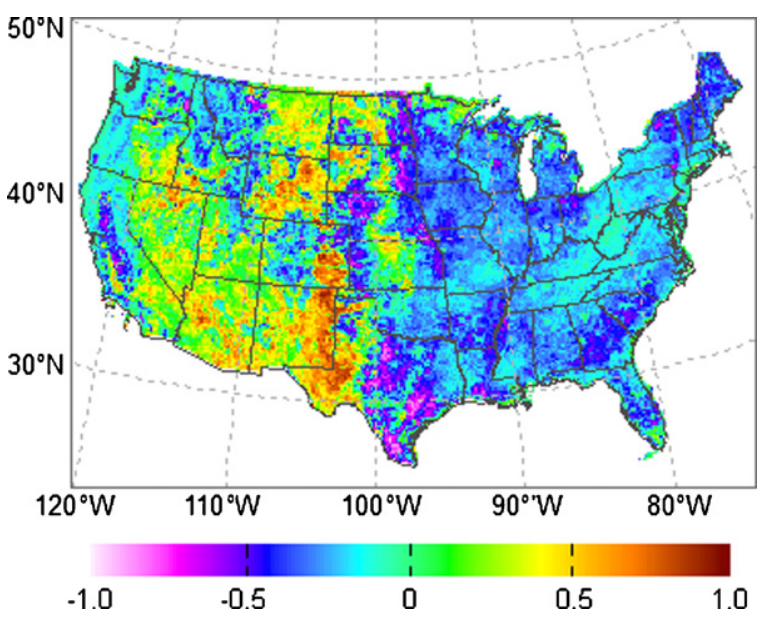

Fig. 8. Interannual variability of annual NEE across the conterminous U.S. over the period 2001-2006 characterized by the coefficient of variation (CV).

ues. These areas had relatively low mean annual NEE in absolute magnitude and were frequently affected by moderate to severe drought (2000-2003 and 2005), leading to relatively large yearto-year variations. Among regions with carbon uptake, a swath of land in Texas and eastern Great Plains exhibited large CV values in absolute magnitude. Most highly productive regions including the Southeast and the Pacific Northwest had relatively low CV, showing that annual NEE of these ecosystems exhibited low year-to-year variations. These regions are characterized by favourable climate conditions, and ecosystems in these regions may not be subject to water stress despite minor to moderate negative precipitation anomalies.

The magnitude of the U.S. terrestrial carbon sink varied between 0.51 and $0.70 \mathrm{pg} \mathrm{C} \mathrm{yr}^{-1}$ from 2001 to 2006 due to climate variability, disturbances, and management practices (Fig. 9). In our 6-yr estimate, 2002 and 2006 were the lowest net uptake years $(0.56$ and $0.51 \mathrm{pg} \mathrm{C} \mathrm{yr}^{-1}$, respectively). The U.S. carbon sink in these two years decreased by $16.3 \%$ and $27.1 \%$ relative to previous years (2001 and 2005, respectively) due to the effects of drought and wildfires. Moderate to extreme drought affected more than $50 \%$ of the conterminous U.S. during the summer in 2002 and 2006 (NCDC, 2008), modifying the balance of ecosystem photosynthesis and respiration in these years. Annual NEE anomaly maps showed large positive anomalies (smaller sinks or sources) in many regions affected by drought (Fig. 9). The impact of the 2002 drought on ecosystem carbon uptake is generally consistent with the drought effects on the terrestrial carbon cycle observed for Europe and North America (Ciais et al., 2005; Peters et al., 2007). Our results also show that (a)

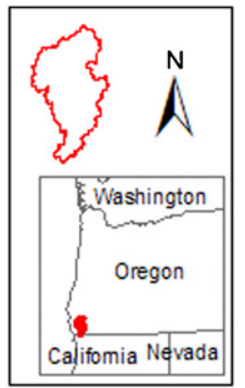

(b)
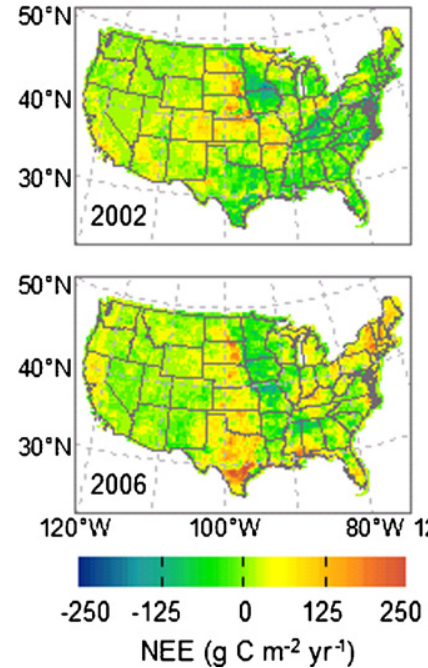
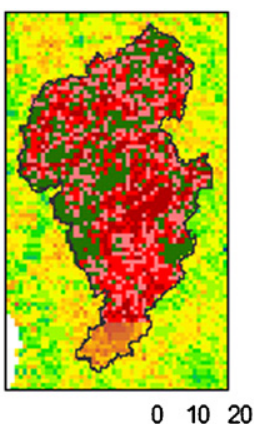

$$
\text { ᄂ }
$$$$
\text { II }
$$

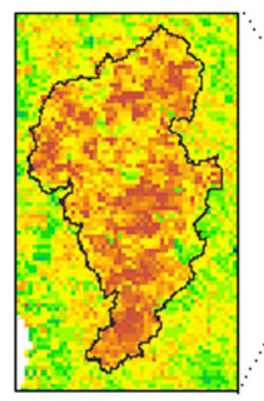

$40 \mathrm{~km}$
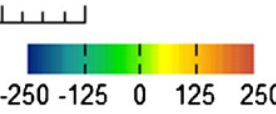

NEE $\left(\mathrm{g} \mathrm{C} \mathrm{m}^{-2} \mathrm{yr}^{-1}\right)$
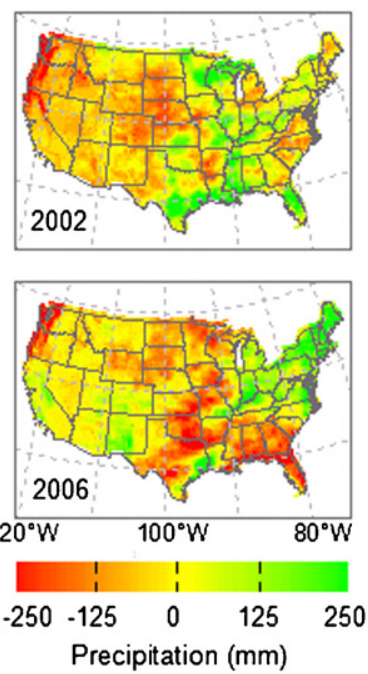

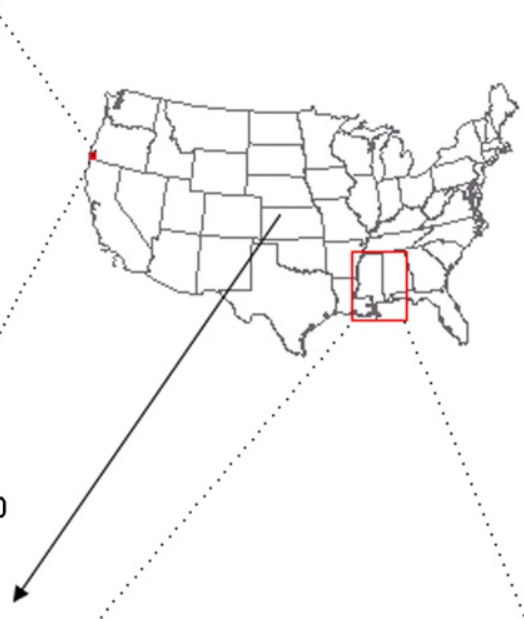

(c)

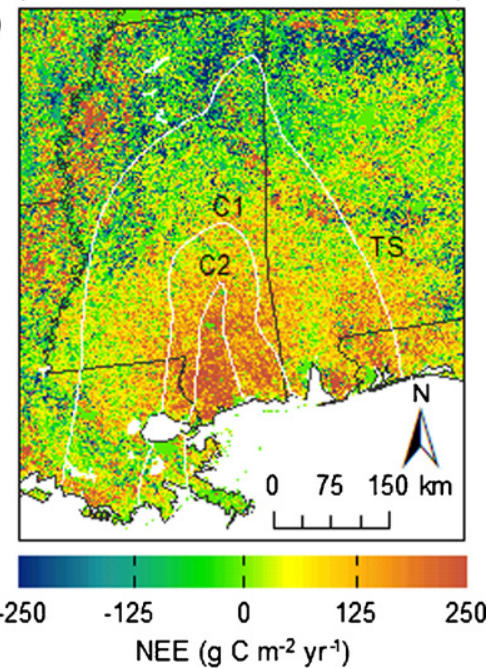

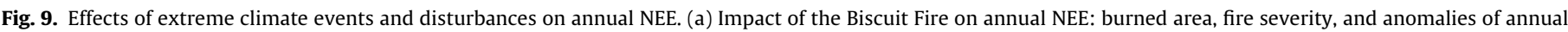

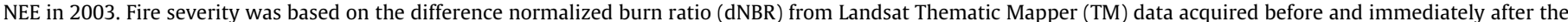

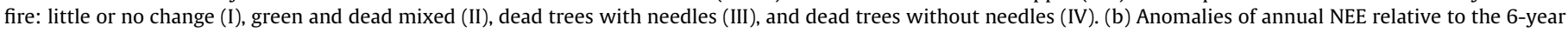

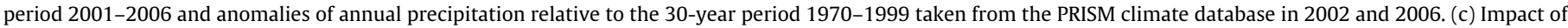
hurricane Katrina on annual NEE in 2006. The white lines indicate the isotachs, including tropical storm, hurricane category 1 , and hurricane category 2. 
the 2006 drought had a larger impact on the U.S. ecosystem carbon exchange than the 2002 drought.

At the stand or regional level, NEE is significantly affected by disturbances (Law et al., 2004). Disturbances can substantially alter ecosystem carbon fluxes and regional carbon budgets (McCarthy et al., 2006; Chambers et al., 2007), by reducing the aboveground biomass and increase litter, thereby leading to a decrease in GPP and an increase in $R_{\mathrm{h}}$. Our results show that disturbances including wildfires and hurricanes could affect regional annual NEE. In addition, numerous wildfires occurred over the western U.S. due to drought conditions related to large-scale atmospheric circulation patterns, burning $1.5-4.0 \times 10^{4} \mathrm{~km}^{2}$ of forests from 2000 to 2006 (U.S. Fire Administration, 2008). Our results indicate that fires had significant impacts on regional carbon budgets. For example, the 2002 Biscuit Fire in Oregon led to large positive NEE anomalies for the forest ecosystems within the fire polygon (Fig. 9). The burn severity of the fire varied over space (Thompson et al., 2007), leading to the significant spatial variability of NEE anomalies. Our results also indicate that other disturbances such as hurricanes affected the interannual variability of NEE at the regional scale. For example, hurricane Katrina that occurred in late August 2005 affected over $2 \times 10^{4} \mathrm{~km}^{2}$ of forest across Mississippi, Louisiana and Alabama, with damage ranging from broken branches to downed trees. Our results show large positive NEE anomalies in areas classified as hurricane category I and II (Fig. 9).

Modeling interannual variation in NEE has proven challenging. The interannual variation in NEE represents an extreme test for models because it is much smaller than seasonal or spatial variation in photosynthesis and respiration (Richardson et al., 2007). Our approach made use of 8-day MODIS products that provided real-time observations of vegetation before and after disturbances, and therefore could partly account for the effects of disturbances on NEE. The current efforts of developing continental-scale dynamic land cover and disturbances products by USGS EROS Data Center and the University of Maryland (Goward et al., 2008) and their incorporation into the model could improve the estimation of NEE. This could affect the ranking of NEE among regions because of different disturbance regimes among regions. For example, forest harvest in the southeastern US is on a very short rotation and disturbance from fire is more prevalent in the interior west. To better characterize disturbance with this approach, an even distribution of disturbance clusters among ecoregions would be beneficial in combination with disturbance mapping at an appropriate spatial and temporal scale for capturing disturbances (Cohen et al., 2002). It is challenging to estimate litterfall and soil carbon pools as a result of disturbance. The availability of disturbance data and the training of the model with eddy flux measurements from flux towers representing different stages following disturbances may improve the accuracy for estimating NEE of forest ecosystems.

\subsection{Sources of uncertainty}

Despite the encouraging performance of our predictive model in estimating NEE and capturing the spatiotemporal patterns and magnitude of U.S. ecosystem carbon exchange, we recognize that our NEE estimates contain significant uncertainties. There are several sources of uncertainty associated with our flux estimates: uncertainties in eddy flux measurements, uncertainties in input data (e.g., land cover), model structural uncertainty, and uncertainties arising from the representativeness of the AmeriFlux network. The carbon flux measurements derived from eddy flux towers contain significant uncertainties (Richardson et al., 2008), while the gap-filling techniques used to fill the data gaps introduced additional uncertainties of $\sim \pm 25 \mathrm{~g} \mathrm{C} \mathrm{m}^{-2} \mathrm{yr}^{-1}$ (Moffat et al., 2007). Land cover is likely the predominant source of uncertainty because different land-cover types are associated with different parameters in our predictive model and the classification uncertainty directly introduces errors into flux estimates. The use of higher-resolution land cover data (e.g., NLCD) may help assess the accuracy of the MODIS land cover map and the effect on NEE estimates.

The model structure could also introduce uncertainty into our NEE estimates. The explanatory variables included in our predictive model could not account for all factors that affect NEE. For example, these variables could not account for nitrogen availability that limits plant growth. Moreover, the explanatory variables could not sufficiently account for the factors affecting $R_{\mathrm{h}}$ : substrate availability, soil temperature, and soil moisture (Xiao et al., 2008). The LST derived from MODIS is a measure of the soil temperature at the surface, and is a good indicator of $R_{\mathrm{e}}$ (Rahman et al., 2005) as both autotrophic and heterotrophic respiration are significantly affected by air/surface temperature (Lloyd and Taylor, 1994). NDWI can partly account for soil moisture (Fensholt and Sandholt, 2003). However, surface reflectance and EVI can only partly account for aboveground biomass and non-photosynthetic material (e.g., litter), and are not sensitive to soil carbon pools. Root and associated mycorrhizal respiration produce roughly half of soil respiration, with much of the reminder derived from decomposition of recently produced root and leaf litter (Ryan and Law, 2005). The inability of our model to account for transient carbon pools could introduce uncertainties to our NEE estimates (Richardson et al., 2007).

The representativeness of the AmeriFlux network will also presumably affect our spatial estimates of carbon fluxes. We speculate that our flux estimates exhibited larger uncertainties in regions under-represented by eddy flux towers. Although the AmeriFlux network is generally representative of the conterminous U.S. ecoregions (Figs. 1 and 2; Hargrove et al., 2003) and the 42 sites used in this study included most of the active flux sites in the network, some geographical regions, ecoregions, and biome types are still underrepresented (Fig. 3; Xiao et al., 2008), which could affect the accuracy of our NEE estimates. In particular, no flux towers have been established for savannas (tree cover 10-30\%), and therefore we merged savannas (tree cover 10-30\%) and woody savannas (tree cover 30-60\%) together in the development of the predictive model (Xiao et al., 2008). Savannas and woody savannas occupy $\sim 4.2 \times 10^{5} \mathrm{~km}^{2}$ of land, and the treatment of savannas as woody savannas could lead to biases to our NEE estimates for savannas. Similarly, no flux towers have been established for open shrublands (shrub canopy cover 10-60\%), and we thus merged open shrublands with closed shrublands (shrub canopy cover $>60 \%$ ). The treatment of open shrublands as closed shrublands could also lead to biases in our NEE estimates. The current AmeriFlux network should be augmented by establishing more sites for the western U.S., more disturbance clusters of sites representing early stages following disturbances, and more sites for certain biomes in the UMD classification system (e.g., open shrublands and savannas) (Xiao et al., 2008).

A comprehensive, quantitative analysis of the uncertainties associated with our flux estimates is beyond the scope of this study. Future upscaling studies, however, should gauge the uncertainty in flux estimates by considering uncertainties of eddy flux measurements, using different upscaling methods, evaluating uncertainties and differences in input data (e.g., classification accuracy of land-cover maps), propagating the probability distributions of parameters through the models, and comparing changes in fluxes caused by systematically removing individual flux tower data from the development of predictive models.

\section{Conclusions}

We produced continuous estimates of NEE with high spatial ( $1 \mathrm{~km}$ ) and temporal (8-day) resolutions over the period 2000-2006 for the conterminous U.S. by integrating eddy flux measurements 
and wall-to-wall MODIS data. Our continuous NEE estimates along with our previous GPP estimates (Xiao et al., 2010), referred to as EC-MOD, were both derived from eddy covariance (EC) and MODIS data. The EC-MOD dataset has high temporal and spatial resolutions, and are highly constrained by eddy covariance data. EC-MOD provides alternative, independent gridded flux estimates for U.S., and is useful for evaluating simulations of ecosystem models and atmospheric inversions.

We examined the spatial patterns, magnitude, and interannual variability of U.S. ecosystem carbon exchange using our continuous NEE estimates. We estimated the terrestrial carbon sink in the

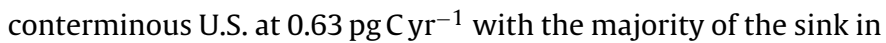
regions dominated by evergreen and deciduous forests and savannas. Our results show that U.S. ecosystems play an important role in slowing down the buildup of $\mathrm{CO}_{2}$ in the atmosphere. Our results also show that recent U.S. annual NEE exhibited significant yearto-year variations. The dominant sources of the recent interannual variation included extreme climate events (e.g., drought) and disturbances (e.g., wildfires, hurricanes). Our results also highlight the need to improve our understanding of the impacts of standreplacing disturbances on the forest carbon budget. Our study provides an alternative, independent, and novel constraint to the net ecosystem carbon exchange of U.S. terrestrial ecosystems.

\section{Acknowledgements}

This study was supported by grants from the National Science Foundation (NSF) and Department of Energy (DOE). We thank the principal investigators and contributors of the MODIS data products, the Oak Ridge National Laboratory (ORNL) Distributed Active Archive Center (DACCC), and the Earth Observing System (EOS) Data Gateway for making these MODIS data products available. The Level I Ecoregions map of North America was obtained from Environmental Protection Agency (EPA), the Biscuit fire severity data from J. Thompson, Harvard University, and the PRISM climate database from the PRISM Group, Oregon State University. Computing support was provided by the Rosen Center for Advanced Computing, Purdue University. We also thank anonymous reviewers and Dr. Anne Verhoef for their valuable comments on earlier versions of the manuscript. [The EC-MOD dataset is available upon request.]

Contributors: J.X. and Q.Z. designed the study; J.X. conducted the research and analyzed the results; J.X. and Q.Z. wrote the paper; B.E.L., D.D.B., J.C., A.D.R., K.J.D., D.Y.H., S.W., R.O., A.N., M.L.F., S.B.V., D.R.C., G.S., S.M., S.C.W., P.V.B., S.P.B., P.S.C., B.G.D., M.F., D.R.F., L.G., J.L.H., G.G.K., M.L., S.M., T.A.M., R.M., T.P.M., R.K.M., J.W.M., W.C.O., K.T.P.U., H.P.S., R.L.S., G.S., A.E.S., and M.S.T. contributed eddy flux data; B.E.L., D.D.B., J.C., A.D.R., J.M.M., K.J.D., D.Y.H., S.W., R.O., A.N., M.L.F., S.B.V., and D.R.C. provided comments on the manuscript. Authors from P.V.B. to M.S.T. are listed alphabetically.

\section{References}

Amiro, B.D., Barr, A.G., Barr, J.G., Black, T.A., Bracho, R., Brown, M., Chen, J., Clark, K.L., Davis, K.J., Desai, A.R., Dore, S., Engel, V., Fuentes, J.D., Goldstein, A.H., Goulden, M.L., Kolb, T.E., Lavigne, M.B., Law, B.E., Margolis, H.A., Martin, T., McCaughey, J.H., Misson, L., Montes-Helu, M., Noormets, A., Randerson, J.T., Starr, G., Xiao, J., in press. Ecosystem carbon dioxide fluxes after disturbance in forests of North America. J. Geophys. Res., doi:10.1029/2010JG001390.

Anthoni, P.M., Unsworth, M.H., Law, B.E., Irvine, J., Baldocchi, D.D., Tuyl, S.V., Moore, D., 2002. Seasonal differences in carbon and water vapor exchange in young and old-growth ponderosa pine ecosystems. Agric. Forest Meteorol. 111, 203-222.

Atlantic Oceanographic and Meteorological Laboratory (AOML), 2007. http://www.aoml.noaa.gov/hrd/Storm_pages/katrina2005.

Baldocchi, D.D., 2003. Asssessing the eddy covariance technique for evaluating carbon dioxide exchange rates of ecosystems: past, present, and future. Global Change Biol. 9, 479-492.

Baldocchi, D.D., Falge, E., Gu, L., Olson, R., Hollinger, D., Running, S., Anthoni, P., Bernhofer, C., Davis, K., Evans, R., Fuentes, J., Goldstein, A., Katul, G., Law, B., Lee, X., Malhi, Y., Meyers, T., Munger, W., Oechel, W., Paw, U.K.T., Pilegaard,
K., Schmid, H.P., Valentini, R., Verma, S., Vesala, T., Wilson, K., Wofsy, S., 2001 FLUXNET: a new tool to study the temporal and spatial variability of ecosystemscale carbon dioxide, water vapor, and energy flux densities. Bull. Am. Meteorol. Soc. 82, 2415-2434.

Baldocchi, D., 2008. 'Breathing' of the terrestrial biosphere: lessons learned from a global network of carbon dioxide flux measurements systems. Aust. J. Bot. 56, $1-26$.

Brewer, C.K., Winne, J.C., Redmond, R.L., Opitz, D.W., Mangrich, M.V., 2005. Classifying and mapping wildfire severity: a comparison of methods. Photogram. Eng. Remote Sens. 71, 1311-1320.

Caspersen, J.P., Pacala, S.W., Jenkins, J.C., Hurtt, G.C., Moorcroft, P.R., Birdsey, R.A 2000. Contributions of land-use history to carbon accumulation in U.S. forests. Science 290, 1148-1151.

Chambers, J.Q., Fisher, J.I., Zeng, H., Chapman, E.L., Baker, D.B., Hurtt, G.C., 2007. Hurricane Katrina's carbon footprint on U.S. Gulf Coast Forest Sci. 318, 1107-11107.

Ciais, P.H., Reichstein, M., Viovy, N., Granier, A., Ogée, J., Allard, V., Aubinet, M. Buchmann, N., Bernhofer, C., Carrara, A., Chevallier, F., Noblet, N.D., Friend, A.D. Friedlingstein, P., Grünwald, T., Heinesch, B., Keronen, P., Knohl, A., Krinner, G., Loustau, D., Manca, G., Matteucci, G., Miglietta, F., Ourcival, J.M., Papale, D., Pilegaard, K., Rambal, S., Seufert, G., Soussana, J.F., Sanz, M.J., Schulze, E.D., Vesala, T., Valentini, R., 2005. Europe-wide reduction in primary productivity caused by the heat and drought in 2003. Nature 437, 529-533.

Clark, D.A., Brown, S., Kicklighter, D.W., Chambers, J.Q., Thomlinson, J.R., Ni, J., 2001 Measuring net primary production in forests: concepts and field methods. Ecol. Appl. 11, 356-370.

Cohen, W.B., Spies, T.A., Alig, R.J., Oetter, D.R., Maiersperger, T.K., Fiorella, M., 2002. Characterizing 23 years (1972-1995) of stand replacement disturbance in western Oregon forests with Landsat imagery. Ecosystems 5, 122-137.

Deng, F., Chen, J.M., Ishizawa, M., Yuen, C.-W., Mo, G., Higuchi, K., Chan, D., Maksyutov, S., 2007. Global monthly $\mathrm{CO}_{2}$ flux inversion with a focus over North America. Tellus 59B, 179-190.

Energy Information Administration, Department of Energy (DOE), 2008. http://www.eia.doe.gov.

Environmental Protection Agency (EPA), 2009, http://www.epa.gov/wed/pages/ ecoregions.htm.

Fensholt, R., Sandholt, I., 2003. Derivation of a shortwave infrared water stress index from MODIS near- and shortwave infrared data in a semiarid environment. Remote Sens. Environ. 87, 111-121.

Friedl, M.A., Mclver, D.K., Hodges, J.C.F., Zhang, X.Y., Muchoney, D., Strahler, A.H Woodcock, C.E., Gopal, S., Schneider, A., Cooper, A., Baccini, A., Gao, F., Schaaf, C., 2002. Global land cover mapping from MODIS: algorithms and early results. Remote Sens. Environ. 83, 287-302.

Gao, B.C., 1996. NDWI-a normalized difference water index for remote sensing of vegetation liquid water from space. Remote Sens. Environ. 58, 257-266.

Göckede, M., Foken, T., Aubinet, M., Aurela, M., Banaz, J., Bernhofer, C., Boonefond, J.M., Brunet, Y., Carrara, A., Clement, R., Dellwik, E., Elbers, J., Eugster, W., Fuhrer, J., Granier, A., Grünwald, T., Heinesch, B., Janssens, I.A., Knohl, A., Koeble, R., Laurila, T., Longdoz, B., Manca, G., Marek, M., Markkanen, T., Mateus, J., Matteucci, G., Mauder, M., Migliavacca, M., Minerbi, S., Moncrieff, J., Montagnani, L., Moors, E., Ourcival, J.-M., Papale, D., Pereira, J., Pilegaard, K., Pita, G., Rambal, S., Rebmann, C., Rodrigues, A., Rotenberg, E., Sanz, M.J., Sedlak, P., Seufert, G., Siebicke, L., Soussana, J.F., Valentini, R., Vesala, T., Verbeeck, H., Yakir, D., 2008. Quality control of CarboEurope flux data. Part 1. Coupling footprint analyses with flux data quality assessment to evaluate sites in forest ecosystems. Biogeosciences 5, 433-450.

Goodale, C.L., Apps, M.J., Birdsey, R.A., Field, C.B., Heath, L.S., Houghton, R.A., Jenkins, J.C., Kohlmaier, G.H., Kurz, W., Liu, S., Nabuurs, G.-J., Nilsson, S., Shvidenko, A.Z. 2002. Forest carbon sinks in the Northern Hemisphere. Ecol. Appl. 12, 891-899.

Goward, S.N., Masek, J.G., Cohen, W., Moisen, G., Collatz, G.J., Healey, S., Houghton, R.A., Huang, C., Kennedy, R., Law, B., Powell, S., Turner, D., Wulder, M.A 2008. Forest disturbance and North American carbon flux. EOS Trans. AGU 89 doi:10.1029/2008EO110001.

Hargrove, W.W., Hoffman, F.M., Law, B.E., 2003. New analysis reveals representativeness of the AmeriFlux network. EOS Trans. 84, 529-544.

Houghton, R.A., Hackler, J.L., Lawrence, K.T., 1999. The U.S. carbon budget: contributions from land-use change. Science $285,574-578$.

Huete, A., Didan, K., Miura, T., Rodriguez, E.P., Gao, X., Ferreira, L.G., 2002. Overview of the radiometric and biophysical performance of the MODIS vegetation indices. Remote Sens. Environ. 83, 195-213.

Intergovernmental Panel on Climate Change, Climate Change 2007 - The Physical Science Basis, 2007. Contribution of Working Group I to the Fourth Assessment Report of the IPCC. Cambridge University Press, New York.

Lal, R., Kimble, J.M., Follett, R.F., Stewart, B.A., 2001. Assessment Methods for Soil Carbon. Advances in Soil Science. Lewis Press, Boca Raton, FL, pp. 676.

Law, B.E., Turner, D., Campbell, J., Sun, O.J., Tuyl, S.V., Ritts, W.D., Cohen, W.B., 2004 Disturbances and climate effects on carbon stocks and fluxes across Western Oregon USA. Global Change Biol. 10, 1429-1444.

Lloyd, J., Taylor, J.A., 1994. On the temperature dependence of soil respiration. Funct. Ecol. 8, 315-323.

Lutes, D.C., Keane, J.F., Caratti, C.H., Key, C.H., Benson, N.C., Gangi, L.J., 2004. FIREMON: Fire Effects Monitoring and Inventory System (US Department of Agriculture Forest Service, Rocky Mountain Research Station, Ogden, UT), Vol. RMRS-GTR164-CD, p. 400.

McCarthy, H.R., Oren, R., Kim, H.-S., Johnsen, K.H., Maier, C., Pritchard, S.G. Davis, M.A., 2006. Interaction of ice storms and management practices on current carbon sequestration in forests with potential mitigation under 
future $\mathrm{CO}_{2}$ atmosphere. J. Geophys. Res. 111, doi:10.1029/2005JD006428, D15103.

Miller, J.D., Yool, S.R., 2002. Mapping forest post-fire canopy consumption in several overstory types using multi-temporal Landsat TM and ETM data. Remote Sens. Environ. 82, 481-496.

Moffat, A.M., Papale, D., Reichstein, M., Hollinger, D.Y., Richardson, A.D., Barr A.G., Beckstein, C., Braswell, B.H., Churkina, G., Desai, A.R., Falge, E., Gove, J.H., Heimann, M., Hui, D., Jarvis, A.J., Kattge, J., Noormets, A., Stauch, V.J., 2007. Comprehensive comparison of gap-filling techniques for eddy covariance net carbon fluxes. Agric. Forest Meteorol. 147, 209-232.

Pacala, S.W., Hurtt, G.C., Baker, D., Peylin, P., Houghton, R.A., Birdsey, R.A., Heath L., Sundquist, E.T., Stallard, R.F., Ciais, P., Moorcroft, P., Caspersen, J.P., Shevliakova, E., Moore, B., Kohlmaier, G., Holland, E., Gloor, M., Harmon, M.E., Fan, S.M., Sarmiento, J.L., Goodale, C.L., Schimel, D., Field, C.B., 2001. Consistent landand atmosphere-based U.S. carbon sink estimates. Science 292, 2316-2320.

Papale, D., Valentini, A., 2003. A new assessment of European forests carbon exchange by eddy fluxes and artificial neural network spatialization. Global Change Biol. 9, 525-535.

Peters, W.P., Jacobson, A.R., Sweeney, C., Andrews, A.E., Conway, T.J., Masarie, K. Miller, J.B., Bruhwiler, L.M.P., Pétron, G., Hirsch, A.I., Worthy, D.E.J., van der Werf, G.R., Randerson, J.T., Wennberg, P.O., Krol, M.C., Tans, P.P., 2007. An atmospheric perspective on North American carbon dioxide exchange: carbontracker. Proc. Natl. Acad. Sci. U.S.A. 104, 18925-18930.

Powell, M.D., Houston, S.H., Amat, L.R., Morisseau-Leroy, N., 1998. The HRD real-time hurricane wind analysis system. J. Wind Eng. Indus. Aero. 77-78, 53-64.

PRISM Group, 2004. Oregon State University, http://www.prismclimate.org.

Rahman, A.F., Sims, D.A., Cordova, V.D., El-Masri, B.Z., 2005. Potential of MODIS EVI and surface temperature for directly estimating per-pixel ecosystem C fluxes. Geophys. Res. Lett. 32, doi:10.1029/2005GL024127, L19404.

Richardson, A.D., Hollinger, D.Y., Aber, J.D., Ollinger, S.V., Braswell, B.H., 2007. Environmental variation is directly responsible for short- but not long-term variation in forest-atmosphere carbon exchange. Global Change Biol. 13, 788-803.

Richardson, A.D., Mahecha, M.D., Falge, E., Kattge, J., Moffat, A.M., Papale, D., Reichstein, M., Stauch, V.J., Braswell, B.H., Churkina, G., Kruijt, B., Hollinger, D.Y., 2008 Statistical properties of random $\mathrm{CO}$ flux measurement uncertainty inferred from model residuals. Agric. Forest Meteorol. 148, 38-50.

RuleQuest, 2008. http://www.rulequest.com. Visited on 10/18/2007.

Ryan, M.G., Law, B.E., 2005. Interpreting, measuring, and modeling soil respiration. Biogeochemistry 73, 3-27.

Schimel, D., Melillo, J., Tian, H., McGuire, A.D., Kicklighter, D., Kittel, T., Rosenbloom, N., Running, S., Thornton, P., Ojima, D., Parton, W., Kelly, R., Sykes, M., Neilson, R., Rizzo, B., 2000. Contribution of increasing $\mathrm{CO}_{2}$ and climate to carbon storage by ecosystems in the United States. Science 287, 2004-2006.

Schmid, H.P., 1994. Source areas for scalars and scalar fluxes. Boundary Layer Meteorol. 67, 293-318.

Snyder, K.A., Tartowski, S.L., 2006. Multi-scale temporal variation in water availability: implications for vegetation dynamics in arid and semi-arid ecosystems. J. Arid Environ. 65, 219-234.

SOCCR, 2007. In: King, A.W., Dilling, L., Zimmerman, G.P., Fairman, D.M., Houghton, R.A., Marland, G.A., Rose, A.Z., Wilbanks, T.J. (Eds.), The First State of the Carbon Cycle Report (SOCCR). The North American Carbon Budget and Implications for the Global Carbon Cycle. US Climate Change Science Program, Washington, DC, p. 19.
Thompson, J.R., Spies, T.A., Ganio, L.M., 2007. Reburn severity in managed and unmanaged vegetation in a large wildfire. Proc. Natl. Acad. Sci. U.S.A. 104, 10743-10748.

U.S. Fire Administration, 2008. http://www.usfa.dhs.gov.

Vermote, E.F., Vermeulen, A., 1999. MODIS Algorithm Technical Background Document - Atmospheric Correction Algorithm: Spectral Reflectances (MOD09), Version 4.0. http://modis.gsfc.nasa.gov/data/atbd/atbd_mod08.pdf.

Wan, Z., Zhang, Y., Zhang, Q., Li, Z.-L., 2002. Validation of the land-surface temperature products retrieved from Terra Moderate Resolution Imaging Spectroradiometer data. Remote Sens. Environ. 83, 163-180.

Waring, R.H., Franklin, J.F., 1979. Evergreen coniferous forests of the Pacific Northwest. Science 204, 1380-1386.

Wiedinmyer, C., Neff, J.C., 2007. Estimates of $\mathrm{CO}_{2}$ from fires in the United States: implications for carbon management. Carbon Balance Manage. 2, doi:10.1186/1750-0680-2-10.

Wofsy, S.C., Goulden, M.L., Munger, J.W., Fan, S.-M., Bakwin, P.S., Daube, B.C., Bassow, S.L., Bazzaz, F.A., 1993. Net exchange of CO in a mid-latitude forest. Science 260, 1314-1317.

Wylie, B.K., Fosnight, E.A., Gilmanov, T.G., Frank, A.B., Morgan, J.A., Haferkamp, M.R., Meyers, T.P., 2007. Adaptive data-driven models for estimating carbon fluxes in the Northern Great Plains. Remote Sens. Environ. 106, 399-413.

Xiao, J., Zhuang, Q., Baldocchi, D.D., Law, B.E., Richardson, A.D., Chen, J., Oren, R., Starr, G., Noormets, A., Ma, S., Verma, S.B., Wharton, S., Wofsy, S.C., Bolstad, P.V., Burns, S.P., Cook, D.R., Curtis, P.S., Drake, B.G., Falk, M., Fischer, M.L., Foster, D.R., Gu, L., Hadley, J.L., Hollinger, D.Y., Katul, G.G., Litvak, M., Martin, T.A. Matamala, R., McNulty, S., Meyers, T.P., Monson, R.K., Munger, J.W., Oechel, W.C., Paw, U.K.T., Schmid, H.P., Scott, R.L., Sun, G., Suyker, A.E., Torn, M.S., 2008. Estimation of net ecosystem carbon exchange for the conterminous United States by combining MODIS and AmeriFlux data. Agric. Forest Meteorol. 148, 1827-1847, doi:10.1016/j.agrformet.2008.06.015.

Xiao, J., Zhuang, Q., Liang, E., McGuire, A.D., Moody, A., Kiclighter, D.W., Shao, X., Melillo, J.M., 2009. Twentieth century droughts and their impacts on terrestrial carbon cycling in China. Earth Interactions 13, 1-31, doi:10.1175/2009EI275.1 (010).

Xiao, J., Zhuang, Q., Law, B.E., Chen, J., Baldocchi, D.D., Cook, D.R., Oren, R., Richardson, A.D., Wharton, S., Ma, S., Martin, T.A., Verma, S.B., Suyker, A.E., Scott, R.L., Monson, R.K., Litvak, M., Hollinger, D.Y., Sun, G., Davis, K.J., Bolstad, P.V., Burns, S.P., Curtis, P.S., Drake, B.G., Falk, M., Fischer, M.L., Foster, D.R., Gu, L., Hadley, J.L., Katul, G.G., Matamala, R., McNulty, S., Meyers, T.P., Munger, J.W., Noormets, A., Oechel, W.C., Paw, U.K.T., Schmid, H.P., Starr, G., Torn, M.S., Wofsy, S.C., 2010. A continuous measure of gross primary production for the conterminous U.S. derived from MODIS and AmeriFlux data. Remote Sens. Environ. 114, 576-591, doi:10.1016/j.rse.2009.10.013.

Yamaji, T., Sakai, T., Endo, T., Baruah, P.J., Akiyama, T., Saigusa, N., Nakai, Y., Kitamura, K., Ishizuka, M., Yasuoka, Y., 2007. Scaling-up technique for net ecosystem productivity of deciduous broadleaved forests in Japan using MODIS data. Ecol. Res. 23, doi:10.1007/s11284-007-0438-0.

Yang, F., Zhu, A.-X., Ichii, K., White, M.A., Hashimoto, H., Nemani, R.R., 2008. Assessing the representativeness of the AmeriFlux network using MODIS and GOES data. J. Geophys. Res. 113, G04036, doi:10.1029/2007JG000627.

Zeng, N., Qian, H., Roedenbeck, C., Heimann, M., 2005. Impact of 1998-2002 midlatitude drought and warming on terrestrial ecosystem and the global carbon cycle. Geophys. Res. Lett. 32, L22709, doi:10.1029/2005GL024607. 